\title{
Mineral Resources: The Bread and Butter of NRR
}

\author{
Emmanuel John M. Carranza ${ }^{1,2}$ \\ Published online: 4 February 2020
}

Our journal Natural Resources Research (NRR) is known traditionally for articles on the development of methods for assessment/estimation of and mapping of potential (or prospectivity) for mineral resources (Carranza 2017, 2018b). In fact, the top 10 most-cited NRR articles published in 2015 and 2016 that contributed significantly to our journal's first impact factor (IF), an astounding 3.094, were all concerned with mineral resources (Carranza 2019). Likewise, although our journal's second IF decreased to 2.000, the top 10 most-cited NRR articles published in 2016 and 2017 that contributed significantly to that were all, but one, concerned with mineral resources (Table 1 ).

However, after our journal received in 2018 its first IF, we have received several submissions and have accepted to publish several articles about other types of natural resources, which our journal seldom published for lack of submissions in the past. For example, last year in 2019, we published a special issue on "Forest, Agriculture, and Environmental Protection as Path to Sustainable Development" and, in our regular issues, there were several articles on groundwater resources.

For this year 2020, we hoped to publish another special issue on mineral resources, namely about
"Data Analysis Tools for Mineral Potential Mapping" exclusive for articles that were presented in the 2018 Annual Conference of the International Association for Mathematical Geosciences. However, for a variety of reasons on the part of the potential contributing authors, we received in 2019 only a few submissions for that planned special issue. Nevertheless, we have accepted in 2019 several submissions of articles on exploration and assessment of mineral resources that were not submitted for that special issue. This first regular issue of volume 29 for NRR replaces that planned special issue. It is deemed better (i.e., for the benefit of readers in mineral resources) to group these articles on exploration and assessment of mineral resources in a single issue. It is hoped that the articles in this present 'virtual special issue' on exploration and assessment of mineral resources will result in several citations that will boost NRR's IF in the coming years.

Starting this year 2020, NRR will be publishing six regular issues per year. That is because of the more than $150 \%$ increase in the number of submissions annually since NRR was included in 2017 in the Science Citation Index Expanded ${ }^{\mathrm{TM}}$ (also known as SciSearch ${ }^{\circledR}$ ), Journal Citation Reports ${ }^{\circledR}$ (JCR)

\footnotetext{
${ }^{1}$ School of Agricultural, Earth and Environmental Sciences, University of KwaZulu-Natal, Durban, Australia.

${ }^{2}$ To whom correspondence should be addressed; e-mail: ejmcarranza@gmail.com
} 
Table 1. Top 10 most-cited NRR articles, published in 2016 (volume 25) and 2017 (volume 26), which contributed significantly to NRR's $2018 \mathrm{IF}$

\begin{tabular}{|c|c|c|c|c|c|}
\hline Article title & Author(s) & Volume & Issue & $\begin{array}{l}\text { Page } \\
\text { range }\end{array}$ & $\begin{array}{l}\text { Citations coun- } \\
\text { ted for NRR's } \\
\text { IF } 2018\end{array}$ \\
\hline $\begin{array}{l}\text { Machine learning of mineralization-related geochemical } \\
\text { anomalies: A review of potential methods }\end{array}$ & Zuo, R. & 26 & 4 & $\begin{array}{c}457- \\
464\end{array}$ & 9 \\
\hline $\begin{array}{l}\text { Application of discriminant analysis and support vector ma- } \\
\text { chine in mapping gold potential areas for further drilling in } \\
\text { the Sari-Gunay Gold Deposit, NW Iran }\end{array}$ & $\begin{array}{l}\text { Geranian, H., Tabatabaei, S. } \\
\text { H., Asadi, H. H., Carranza, } \\
\text { E. J. M. }\end{array}$ & 25 & 2 & $\begin{array}{c}145- \\
159\end{array}$ & 7 \\
\hline $\begin{array}{l}\text { Enhancement and mapping of weak multivariate stream } \\
\text { sediment geochemical anomalies in Ahar area, NW Iran }\end{array}$ & $\begin{array}{l}\text { Parsa, M., Maghsoudi, A., } \\
\text { Carranza, E. J. M., Yousefi, } \\
\text { M. }\end{array}$ & 26 & 4 & $\begin{array}{c}443- \\
455\end{array}$ & 7 \\
\hline $\begin{array}{l}\text { Data-driven predictive modeling of mineral prospectivity } \\
\text { using random forests: A case study in Catanduanes Island } \\
\text { (Philippines) }\end{array}$ & $\begin{array}{l}\text { Carranza, E. J. M., Laborte, } \\
\text { A. G. }\end{array}$ & 25 & 1 & $\begin{array}{c}35- \\
50\end{array}$ & 6 \\
\hline $\begin{array}{l}\text { Application of global particle swarm optimization for inver- } \\
\text { sion of residual gravity anomalies over geological bodies } \\
\text { with idealized geometries }\end{array}$ & Singh, A., Biswas, A. & 25 & 3 & $\begin{array}{c}297- \\
314\end{array}$ & 6 \\
\hline $\begin{array}{l}\text { Metallic mineral resources in the twenty-first century. I. } \\
\text { Historical extraction trends and expected demand }\end{array}$ & Douce-Patiño, A. E. & 25 & 1 & $\begin{array}{c}71- \\
90\end{array}$ & 6 \\
\hline $\begin{array}{l}\text { Metallic mineral resources in the twenty-first century: II. } \\
\text { Constraints on future supply }\end{array}$ & Douce-Patiño, A. E. & 25 & 2 & $\begin{array}{l}97- \\
124\end{array}$ & 6 \\
\hline Production decline curves of tight oil wells in eagle ford shale & $\begin{array}{l}\text { Wachtmeister, H., Lund, L., } \\
\text { Aleklett, K., Höök, M. }\end{array}$ & 26 & 3 & $\begin{array}{c}365- \\
377\end{array}$ & 6 \\
\hline $\begin{array}{l}\text { Natural resources research publications on geochemical } \\
\text { anomaly and mineral potential mapping, and introduction } \\
\text { to the special issue of papers in these fields }\end{array}$ & Carranza, E. J. M. & 26 & 4 & $\begin{array}{c}379- \\
410\end{array}$ & 5 \\
\hline $\begin{array}{l}\text { Data-driven index overlay and Boolean logic mineral } \\
\text { prospectivity modeling in greenfields exploration }\end{array}$ & $\begin{array}{l}\text { Yousefi, M., Carranza, E. J. } \\
\text { M. }\end{array}$ & 25 & 1 & $3-18$ & 4 \\
\hline
\end{tabular}

\begin{abstract}
Science Edition, and Current Contents ${ }^{\circledR} /$ Physical Chemical and Earth Sciences (Carranza 2018a).
\end{abstract}

\section{REFERENCES}

Carranza, E. J. M. (2017). Natural Resources Research publications on geochemical anomaly and mineral potential map- ping, and introduction to the special issue of papers in these fields. Natural Resources Research, 26(4), 379-410.

Carranza, E. J. M. (2018a). Exciting years ahead for NRR. Natural Resources Research, 27(1), 1-3.

Carranza, E. J. M. (2018b). Natural Resources Research publications on resourcing future generations, and introduction of papers in this special issue. Natural Resources Research, 27(2), 125-141.

Carranza, E. J. M. (2019). An astounding first impact factor for NRR. Natural Resources Research, 28(1), 1-3. 